\title{
KETAHANAN BEBERAPA KULTIVAR CABAI TERHADAP CUCUMBER MOSAIC VIRUS DAN CHILLI VEINAL MOTTLE VIRUS
}

\author{
Muhammad Taufik ${ }^{1}$, Sri Hendrastuti Hidayat ${ }^{1}$, Sriani Sujiprihati ${ }^{2}$, \\ Gede Suastika $^{1}$ dan Sientje Mandang Sumaraw ${ }^{1}$
}

\begin{abstract}
Resistance Evaluation of Chillipepper Cultivars for Cucumber Mosaic Virus and Chilli Veinal Mottle Virus. The use of resistance culivars is an important strategy for management of virus infection in chillipepper. A research was undergone to study the effect of single and mix infection of CMV and ChiVMV on the disease incidence and on the growth and yield of nine chillipepper cultivars, i.e. Cilibangi 4, Cilibangi 5, Cilibangi 6, Helem, Jatilaba, Tit Bulat, Tit Segitiga, Tit Super and Tampar. Mechanical inoculation was conducted to transmit the virus. Infection of the virus was then confirmed with DASELISA. In general, inoculated chillipepper cultivars developed similar symptoms, i.e. mosaic type for CMV and mottle type for ChiVMV. More severe symptom was not always observed from mix infection of CMV and ChiVMV. Disease incidence occurred in the range of $16.67-86.0 \%$ and this caused $18.3-98.6 \%$ yield loss. Based on symptom expression, ELISA result, and reduction on yield, it can be concluded that all chillipepper cultivars used in this study could not hold up the virus infection. However, several cultivars showed tolerance response : Jatilaba, Tit Super, and Tampar for CMV; Cilibangi 4 for ChiVMV; Tit Super for mix infection; and Cilibangi 5 for CMV, ChiVMV, and mix infection. Further evaluation and investigation involving different chillipepper cultivars should be conducted.
\end{abstract}

Key words: Cucumber mosaic virus, chilli veinal mottle virus, Resistance

\section{PENDAHULUAN}

Tanaman cabai adalah salah satu komoditi hortikultura yang penting di Indonesia, namun beberapa kendala produksi dapat menyebabkan kehilangan hasil yang nyata. Salah satu kendala produksi terpenting dalam budidaya tanaman cabai adalah infeksi virus. Jenis virus yang dilaporkan dapat menginfeksi tanaman cabai di Indonesia, diantaranya adalah cucumber mosaic virus (CMV), chili veinal mottle virus (ChiVMV), tobacco mosaic virus (TMV), tomato mosaic virus (ToMV), tobacco etch virus (TEV), pepper mottle virus (PeMV), tomato spotted wilt virus (TSWV), dan potato virus $Y$ (PVY) (Sulyo \& Duriat, 1996). Hasil survei lapang yang dilakukan oleh Taufik, Astuti \& Hidayat (2005) membuktikan bahwa CMV dan ChiVMV memiliki daerah penyebaran yang cukup luas di Indonesia. Kedua virus tersebut selalu ditemukan pada setiap pertanaman cabai yang diamati walaupun proporsi kejadian penyakitnya berbeda-beda untuk setiap tempat. Adanya infeksi ganda oleh CMV dan ChiVMV juga ditemukan dalam pengamatan. Selanjutnya dilaporkan bahwa infeksi CMV atau ChiVMV secara tunggal maupun secara bersamasama pada tanaman cabai menyebabkan penghambatan terhadap pertambahan tinggi tanaman, dan perkembangan cabang tanaman (Taufik et al., 2005).

Pengendalian penyakit yang disebabkan oleh virus relatif sulit dilakukan. Virus sangat bergantung pada komponen inang untuk replikasinya (Matthews 1991; Voyles 2002; Hull, 2002), sehingga aplikasi senyawa antiviral mungkin dapat bersifat fitotoksik terhadap tanaman inang. Virus tanaman mempunyai keragaman genetik yang tinggi serta mekanisme replikasi dan patogenesisnya sangat kompleks. Kebanyakan penularan virus di alam terjadi melalui kutudaun dan bersifat non persisten (Palukaitis et al., 1992; Suric et al., 1999) sehingga target pengendalian menjadi lebih luas dan sulit (Hull, 2002). Penggunaan kultivar tahan merupakan upaya pengendalian yang perlu dikembangkan. Salah satu keuntungan penanaman kultivar tahan adalah tidak diperlukan perlakuan khusus. Selain itu kultivar yang tahan atau toleran bersifat selektif dan secara ekologis aman dan dapat dikombinasikan dengan metode pengendalian lain seperti biokontrol atau dengan pestisida sekalipun (Fraser, 1992).

Kultivar cabai komersial yang memiliki sifat ketahanan terhadap virus masih sangat terbatas jenisnya, termasuk kultivar yang tahan terhadap lebih

\footnotetext{
${ }^{1}$ Departemen Proteksi Tanaman, Fakultas Pertanian, IPB, Jl. Kamper, Kampus IPB Darmaga, Bogor 16680, e-mail : shidayat@ ipb.ac.id

${ }^{2}$ Departemen Agronomi dan Hortikultura, Fakultas Pertanian, Institut Pertanian Bogor, Kampus Darmaga, Bogor 16680
} 
dari satu macam virus. Oleh karena itu usaha untuk mencari varietas yang tahan terhadap berbagai macam patogen, termasuk virus, perlu dilakukan. Evaluasi ketahanan varietas cabai terhadap patogen harus terus menerus dilakukan karena kemampuan patogen untuk membentuk strain-strain yang baru dapat mematahkan ketahanan suatu varietas yang telah dilepas. Hasil evaluasi ketahanan sembilan kultivar cabai terhadap infeksi tunggal CMV atau ChiVMV maupun infeksi campuran CMV dan ChiVMV dilaporkan dalam tulisan ini.

\section{METODE PENELITIAN}

Perbanyakan Inokulum Virus. Sumber inokulum CMV diperoleh dari Balai Penelitian Tanaman Hias Segunung sedangkan sumber inokulum ChiVMV adalah koleksi Laboratorium Virologi IPB. Perbanyakan inokulum CMV dan ChiVMV dilakukan secara inokulasi mekanis berturut-turut pada tanaman tembakau (Nicotiana tabacum var. Samsun NN) dan tanaman paprika (Capsicum annuиm var. Grosum). Sumber inokulum CMV dan ChiVMV masing-masing digerus dalam mortar steril. Larutan penyangga fosfat $0.01 \mathrm{M}(\mathrm{pH}$ 7) ditambahkan dengan perbandingan $1 \mathrm{~g}$ daun terinfeksi virus tiap $5 \mathrm{ml}$ larutan penyangga fosfat $(1: 5 \mathrm{~b} / \mathrm{v})$. Cairan perasan tanaman ini segera diinokulasikan ke tanaman tembakau atau paprika. Sebelum diinokulasi serbuk karborundum ditebarkan pada bagian permukaan atas daun, kemudian cairan perasan tanaman dioleskan dengan kapas steril pada permukaan daun. Segera setelah pengolesan cairan perasan tanaman dilakukan pembilasan sisa-sisa cairan perasan yang masih melekat pada permukaan daun tanaman uji menggunakan air mengalir.

Perbanyakan dan Pemeliharaan Tanaman Cabai. Kultivar tanaman cabai yang digunakan dalam penelitian ialah Cilibangi 4, Cilibangi 5, Cilibangi 6, Helem, Jatilaba, Tit Bulat, Tit Segitiga, Tit Super dan Tampar. Benih tanaman cabai disemai pada media tanah yang dicampur dengan pupuk kandang dengan perbandingan 1:3 dan telah disterilkan, serta dibiarkan selama tiga hari. Setelah muncul daun pertama, bibit tanaman cabai dipindahkan ke dalam polibag dan dipelihara dengan melakukan pemupukan dan penyemprotan pestisida.
Inokulasi CMV dan ChiVMV. Perlakuan inokulasi virus pada tanaman cabai terdiri atas CMV, ChiVMV serta campuran CMV dan ChiVMV. Penyiapan sumber inokulum CMV atau ChiVMV dilakukan dengan metode seperti diuraikan sebelumnya. Sumber inokulum campuran CMV dan ChiVMV dipersiapkan dengan mencampurkan sumber inokulum CMV dan ChiVMV yang disiapkan terpisah dengan perbandingan volume $1: 1$. Untuk perlakuan kontrol, tanaman sehat dioles dengan larutan penyangga fosfat. Semua perlakuan inokulasi pada bibit cabai dilakukan dua kali yaitu inokulasi pertama pada kotiledon ketika bibit cabai berumur 2 minggu, dan inokulasi kedua dilakukan satu minggu setelah inokulasi pertama. Tanaman cabai yang telah diinokulasi dipelihara di dalam rumah kaca sampai berproduksi. Pemeliharaan tanaman dilakukan seoptimal mungkin, meliputi penyiangan, pemupukan, pengairan dan penyemprotan insektisida secara berkala.

Deteksi Virus. Deteksi virus pada tanaman cabai uji dilakukan dengan metode DAS-ELISA (Double antibody sandwich enzyme-linked immunosorbent assay) (Van Regenmortel \& Dubs 1993). Pertamatama plat mikrotiter ELISA diisi dengan 100 ul antibodi CMV atau ChiVMV. Setelah inkubasi pada suhu 4C selama semalam, plat mikrotiter dicuci dengan larutan bufer fosfat saline tween-20 (PBST) dan selanjutnya diisi dengan cairan tanaman uji sebanyak 100 ul. Cairan tanaman uji disiapkan dengan menggerus daun cabai sebanyak $0.01 \mathrm{~g}$ dalam 100 ul larutan bufer ekstraksi. Cairan tanaman uji diinkubasi dalam plat mikrotiter pada suhu 4C selama semalam dan dicuci kembali dengan larutan PBST. Tahapan selanjutnya adalah mengisi plat mikrotiter dengan enzyme conjugate sebanyak 100 ul. Setelah inkubasi selama 2 jam pada suhu ruang, sumuran plat mikrotiter dicuci dengan larutan PBST dan kemudian dimasukkan para-nitrophenyl phosphat (PNP) sebanyak 100 ul per sumuran plat mikrotiter dan diinkubasi selama 30 menit. Reaksi dihentikan dengan menambahkan 50 ul natrium hidroksida $3 \mathrm{M}$.

Deteksi virus dengan DAS-ELISA dilakukan dua kali, yaitu 2 minggu setelah inokulasi kedua pada tanaman cabai dan 2 minggu setelah deteksi yang pertama. Analisis kuantitatif hasil ELISA dilakukan dengan mengukur nilai absorbansi (OD $405 \mathrm{~nm}$ ) menggunakan microplate reader (Biorad model 550). 
Selanjutnya nilai absorban tersebut digunakan untuk menentukan reaksi positif hasil ELISA, yaitu dengan mencari nilai standar deviasinya. Kisaran nilai absorban tanaman yang positif terinfeksi virus adalah dua kali nilai kontrol negatif \pm nilai standar deviasi.

\section{Pengelompokan Tipe Ketahanan Tanaman Cabai Terhadap Infeksi CMV dan ChiVMV. Pengelompokan ketahanan tanaman dilakukan mengikuti penggolongan yang telah dikemukakan oleh Green (1991) dengan sedikit perubahan (Tabel 1). Data yang diperlukan untuk pengelompokan ketahanan kultivar cabai uji terdiri dari keparahan gejala, hasil ELISA, dan hasil analisis bobot buah setiap tanaman.}

Pengamatan dan Rancangan Percobaan. Kultivar cabai uji ditanam di rumah kaca kedap serangga Kebun Percobaan Cikabayan-Darmaga, IPB pada bulan Mei sampai Oktober 2004. Percobaan menggunakan Rancangan Petak Terbagi dengan rancangan dasar Rancangan Acak Kelompok yang terdiri atas tiga kelompok, dengan perlakuan inokulasi virus (I) sebagai petak utama, dan 9 kultivar cabai sebagai anak petak. Setiap perlakuan terdiri atas 2 tanaman. Perlakuan inokulasi virus (I) terdiri atas empat taraf yaitu: $\mathrm{I}_{0}=$ kontrol, $\mathrm{I}_{1}=\mathrm{CMV}, \mathrm{I}_{2}=$ ChiVMV, $\mathrm{I}_{3}=\mathrm{CMV}$ dan ChiVMV. Anak petak terdiri atas kultivar Cilibangi 4, Cilibangi 5, Cilibangi 6, Helem, Jatilaba, Tit Bulat, Tit Segitiga, Tit Super dan Tampar. Total unit percobaan adalah 216 tanaman.
Selain pengamatan kejadian penyakit berdasarkan gejala dan hasil ELISA, peubah lain yang diamati adalah (a) Tinggi tanaman, yang diukur pada umur tanaman 5 minggu setelah tanam; (b) Jumlah cabang, yang diukur pada umur tanaman 11 minggu setelah tanam; dan (c) Bobot buah/tanaman yang dihitung dua kali yaitu pada periode pembungaan ke1 dan ke-2 . Persentase penghambatan tinggi dan jumlah cabang, serta penurunan bobot buah dihitung dengan menggunakan rumus sebagai berikut :

$$
P_{1,2,3}=\frac{\mathrm{K}_{1,2,3}-\mathrm{T}_{1,2.3}}{\mathrm{~K}_{1,2,3}} \times 100 \%
$$

Keterangan : $P_{1}$ : persentase penghambatan tinggi tanaman; $\mathrm{P}_{2}$ : persentase penghambatan jumlah cabang; P3: persentase penurunan bobot buah ; $\mathrm{K}_{1}$ : rata-rata pertambahan tinggi tanaman pada perlakuan kontrol ; $\mathrm{K}_{2}$ : rata-rata jumlah cabang tiap tanaman pada perlakuan kontrol; K3: rata-rata bobot buah tiap tanaman pada perlakuan kontrol; $\mathrm{T}_{1} \quad$ : rata-rata pertambahan tinggi tanaman yang diinokulasi virus; $\mathrm{T}_{2}$ : rata-rata jumlah cabang tiap tanaman pada tanaman yang diinokulasi virus; T3: rata-rata bobot buah tiap tanaman pada tanaman yang diinokulasi virus

\section{HASIL DAN PEMBAHASAN}

Kejadian Penyakit dan Gejala Penyakit. Sembilan

Tabel 1 Pengelompokan tipe ketahanan tanaman berdasarkan respon tanaman terhadap infeksi CMV dan ChiVMV

\begin{tabular}{|c|c|c|c|}
\hline Tipe ketahanan & Gejala & $\begin{array}{c}\text { Kejadian Penyakit } \\
\text { (berdasarkan hasil ELISA) }\end{array}$ & $\begin{array}{c}\text { Pengurangan Bobot } \\
\text { Buah }\end{array}$ \\
\hline Tahan & - & - & - \\
\hline Agak Tahan & $+/-$ & + & - \\
\hline Toleran & + & + & - \\
\hline Rentan & + & + & + \\
\hline Sangat Rentan & ++ & ++ & + \\
\hline $\begin{array}{r}\text { terangan: }+= \\
-= \\
+/-= \\
++=\end{array}$ & $\begin{array}{l}\text { asil ELI } \\
\text { ntrol } \\
\text {, hasil I } \\
\text { s, hasil } \mathrm{E} \\
\text { il ELISA } \\
\text { bobot b }\end{array}$ & $\begin{array}{l}\text { itif, ada pengurangan bob } \\
\text { egatif, tidak ada penguran } \\
\text { sitif, pengurangan bobot bu } \\
\text { dengan kejadian penyakit let } \\
\text { berbeda nyata dibandingkan }\end{array}$ & $\begin{array}{l}\text { ah yang berbeda ny } \\
\text { obot buah dibanding } \\
\text { ak berbeda nyata } \\
\text { i } 50 \% \text { ), } \\
\text { ol }\end{array}$ \\
\hline
\end{tabular}


kultivar cabai yang diinokulasi dengan CMV menunjukkan gejala mosaik sistemik yang beragam mulai dari mosaik berat sampai ringan pada 14 hari setelah inokulasi (HSI) (Tabel 2). Pada daun muda gejala mosaik diawali dengan menguningnya tulang tulang daun (vein clearing) yang dimulai dari pangkal batang; sedangkan pada daun-daun yang lebih tua terbentuk pola mosaik yang kadang-kadang diikuti dengan menyempitnya lebar daun dan malformasi daun. Kejadian penyakit akibat infeksi CMV bervariasi pada setiap kultivar cabai yang diuji. Kejadian penyakit tertinggi terjadi pada kultivar Cilibangi $6(66,67 \%)$, sedangkan yang terendah pada kultivar Helem, Tit super dan Tampar masing sebesar $33.33 \%$.

Inokulasi dengan ChiVMV menghasilkan gejala belang yang juga beragam (Tabel 3). Gejala yang berat ditandai dengan adanya bercak hijau yang tidak beraturan, biasanya permukaan daun tidak rata, daun menjadi lebih kecil atau daun membentuk seperti mangkok atau melengkung kebawah. Ciri khas adanya infeksi ChiVMV adalah ujung daun meruncing dan kadang membentuk seperti benang pada bagian paling ujung dari daun. Gejala ChiVMV yang ringan hanya terlihat berupa bercak hijau pada permukaan daun. Kejadian penyakit tertinggi terjadi pada kultivar Tit Bulat $(83,33 \%)$, sedangkan yang terendah pada kultivar Tit Super (16,67\%) (Tabel 3).

Inokulasi campuran CMV dan ChiVMV menghasilkan gejala yang beragam. Beberapa tanaman hanya menunjukkan gejala mosaik atau belang, tetapi gejala bercampurnya mosaik dan belang dapat pula ditemukan, yaitu pada kultivar Tit
Segitiga. Kejadian penyakit tertinggi akibat inokulasi campuran CMV dan ChiVMV hanya mencapai 66,67 \%, yaitu pada kultivar Cilibangi 6 dan kejadian penyakit terendah mencapai 33,33 \% pada kultivar Cilibangi 5 dan Tampar (Tabel 4).

Hasil deteksi dengan ELISA membuktikan bahwa semua tanaman yang menunjukkan gejala berasosiasi dengan infeksi virus yang diuji. Beberapa tanaman yang tidak menunjukkan gejala ternyata memberikan reaksi positif dengan ELISA. Walaupun demikian, tanaman-tanaman tersebut pada perkembangan selanjutnya mengalami penghambatan pertumbuhan. Kejadian tersebut terjadi pada kultivar Cilibangi 4 dimana tanaman tidak menunjukkan gejala tetapi terjadi penurunan bobot buah. Fenomena seperti ini oleh Antoniw et al. (1990) disebut sebagai infeksi virus cryptic. Lebih lanjut diuraikan bahwa infeksi virus yang tidak menunjukkan gejala dapat menyebabkan kehilangan hasil yang tinggi pada tanaman.

Pengaruh infeksi virus terhadap pertumbuhan dan komponen produksi tanaman cabai. Tanaman yang terinfeksi CMV, ChiVMV, dan campuran CMV dan ChiVMV mengalami gangguan dalam proses pertumbuhannya. Bila tanaman tidak diinokulasi virus (perlakuan kontrol), perbandingan tinggi tanaman, jumlah cabang, dan bobot buah antar kultivar cabai tidak berbeda nyata (Tabel 5). Penghambatan tinggi tanaman karena inokulasi CMV, ChiVMV, dan campuran CMV dan ChiVMV berturut-turut berkisar antara 8,3 - 69\%, 16,3 - 46,9\%, dan 16,4 - 47,5\% (Tabel 5). Penghambatan tertinggi (69\%) terjadi pada

Tabel 3. Kejadian penyakit (KP) dan jenis gejala akibat inokulasi ChiVMV pada sembilan kultivar cabai yang diuji.

\begin{tabular}{lll}
\hline \multicolumn{1}{c}{ Kultivar } & \multicolumn{1}{c}{ KP $(\%)^{*}$} & \multicolumn{1}{c}{ Jenis gejala } \\
\hline Cilibangi 4 & $3 / 6(50,00)$ & Belang, permukaan daun tidak rata \\
Cilibangi 5 & $2 / 6(33,33)$ & Belang ringan \\
Cilibangi 6 & $3 / 6(50,00)$ & Belang, daun melengkung kebawah dan kaku \\
Helem & $3 / 6(50,00)$ & Belang, tanaman kerdil \\
Jatilaba & $2 / 6(33,33)$ & Belang ringan, daun berbentuk seperti mangkok, tanaman kerdil \\
Tit Bulat & $5 / 6(83,33)$ & Belang-belang dan kerdil, daun kaku dan melengkung keatas, malformasi \\
& & daun \\
Tit Segitiga & $2 / 6(33,33)$ & Belang, daun melengkung ke atas, tanaman kerdil \\
Tit Super & $1 / 6(16,67)$ & Belang ringan \\
Tampar & $3 / 6(50,00)$ & Belang ringan, ukuran daun menjadi lebih kecil \\
* KP adalah rasio antara jumlah tanaman yang memberikan reaksi positif pada ELISA dan jumlah total \\
\multicolumn{2}{l}{ tanaman yang diuji }
\end{tabular}


Tabel 4. Kejadian penyakit (KP) dan jenis gejala akibat inokulasi campuran CMV dan ChiVMV pada sembilan kultivar cabai yang diuji.

\begin{tabular}{lrl}
\hline \multicolumn{1}{c}{ Kultivar } & KP $(\%)$ & \multicolumn{1}{c}{ Jenis gejala } \\
\hline Cilibangi 4 & $3 / 6(50,00)$ & Tulang daun menebal, daun kecil dan melengkung ke atas, tanaman kerdil \\
Cilibangi 5 & $2 / 6(33,33)$ & Belang ringan \\
Cilibangi 6 & $4 / 6(66,67)$ & Belang ringan \\
Helem & $3 / 6(50,00)$ & Mosaik ringan, tanaman kerdil \\
Jatilaba & $3 / 6(50,00)$ & Belang ringan \\
Tit Bulat & $3 / 6(50,00)$ & Mosaik,daun kecil, ujung daun meruncing, tanaman kerdil \\
Tit Segitiga & $3 / 6(50,00)$ & Belang bercampur warna kekuningan, ujung daun meruncing, daun kecil \\
& & dan kaku \\
Tit Super & $3 / 6(50,00)$ & Belang, permukaan daun tidak rata, tanaman kerdil \\
Tampar & $2 / 6(33,33)$ & Belang, daun melengkung ke atas \\
\hline
\end{tabular}

* KP adalah rasio antara jumlah tanaman yang memberikan reaksi positif pada ELISA dan jumlah total tanaman yang diuji

perlakuan inokulasi CMV pada kultivar Tit Segitiga, sedangkan penghambatan terendah $(8,3 \%)$ terjadi pada perlakuan inokulasi CMV pada kultivar Tampar. Bila dilakukan analisis pengaruh masing-masing perlakuan inokulasi virus terhadap penghambatan tinggi tanaman pada satu kultivar cabai tampak keragaman respon (tinggi tanaman) setiap kultivar cabai. Respon kultivar Cilibangi 5 dan Jatilaba terhadap setiap perlakuan inokulasi virus tidak berbeda nyata dengan perlakuan kontrol, sebaliknya kultivar Cilibangi 6, Tit Bulat, dan Tit Segitiga memberikan respon yang berbeda nyata.

Penghambatan jumlah cabang karena inokulasi CMV, ChiVMV, dan campuran CMV dan ChiVMV berturut-turut berkisar antara 23,6 - 87,5\%, 17,8 $82,8 \%$, dan 33,6 - 70,2\% (Tabel 5). Penghambatan tertinggi $(87,5 \%)$ terjadi pada perlakuan inokulasi CMV pada kultivar Tit Segitiga, sedangkan penghambatan terendah $(17,8 \%)$ terjadi pada perlakuan inokulasi ChiVMV pada kultivar Cilibangi 5. Secara umum, setiap perlakuan inokulasi virus pada masing-masing kultivar menyebabkan penghambatan jumlah cabang yang berbeda nyata dengan perlakuan kontrol, kecuali pada kultivar Cilibangi 5.

Potensi produksi sembilan kultivar cabai yang diuji sangat beragam, walaupun tidak terdapat perbedaan bobot buah per tanaman antar kultivar. Perlakuan inokulasi virus menyebabkan penurunan produksi yang cukup nyata (Tabel 5). Tiga kultivar, yaitu Tit Segitiga, Tit Super, dan Tampar memiliki potensi produksi yang baik tetapi ternyata ketiganya memiliki kerentanan yang cukup tinggi terhadap infeksi virus. Kultivar Tit Segitiga mengalami penurunan produksi yang tertinggi $(98,6 \%)$ pada perlakuan inokulasi CMV. Kemampuan infeksi CMV menekan produksi pada kultivar Tit Segitiga sesuai dengan laporan Sulyo (1984) yang menyatakan bahwa infeksi CMV pada pertanaman cabai dapat menurunkan hasil panen sampai 50\% jika infeksi terjadi pada umur 4-7 minggu setelah tanam, bahkan pada tingkat serangan lanjut dapat menyebabkan kegagalan panen.

Aspek umum yang dapat diamati pada tanaman terinfeksi virus adalah penurunan jumlah karbohidrat. Hull (2002) melaporkan infeksi kotiledon Cucurbita pepo yang terinfeksi dengan CMV menyebabkan penurunan laju akumulasi pati. Pada fase awal infeksi virus ditandai dengan akumulasi pati yang cepat dan sebaliknya pada fase akhir infeksi virus terjadi penurunan kemampuan untuk mengakumulasi dan mensintesis pati dan pada saat yang bersamaan terjadi peningkatan untuk mendegradasi pati. Efek yang lain adalah tanaman kehilangan kemampuan untuk menghasilkan senyawa-senyawa antara (fosforilasi) termasuk asam organik, gula, asam amino dan protein yang berperan penting untuk menghasilkan senyawa yang dibutuhkan dalam perkembangan tanaman. Pada tahap akhir infeksi dicirikan dengan meningkatnya respirasi tanaman terinfeksi (Goodman et al., 1986, Christopher et al., 1989) dan secara fundamental 
Tabel 5. Pengaruh inokulasi virus terhadap persen penghambatan tinggi tanaman, jumlah cabang/tanaman dan bobot buah (g)/tanaman

\begin{tabular}{|c|c|c|c|c|c|c|c|c|c|c|c|c|}
\hline \multirow[t]{3}{*}{ Kultivar } & \multicolumn{12}{|c|}{$\begin{array}{l}\text { Tinggi tanaman }{ }^{1)} \text {, jumlah cabang /tanaman }{ }^{1)} \text { dan bobot buah }(\mathrm{g}) / \operatorname{tanaman}{ }^{1)} \\
\text { pada masing-masing perlakuan inokulasi virus }\end{array}$} \\
\hline & \multicolumn{3}{|c|}{ Kontrol } & \multicolumn{3}{|c|}{ CMV } & \multicolumn{3}{|c|}{ ChiVMV } & \multicolumn{3}{|c|}{ CMV dan ChiVMV } \\
\hline & $\begin{array}{l}\text { Tinggi } \\
(\mathrm{cm})\end{array}$ & $\begin{array}{c}\text { Cabang } \\
\text { /tanaman }\end{array}$ & $\begin{array}{l}\text { Pertambahan } \\
\text { bobot }(\%)\end{array}$ & $\begin{array}{l}\text { Tinggi } \\
(\mathrm{cm})\end{array}$ & $\begin{array}{l}\text { Cabang } \mathrm{F} \\
\text { /tanaman }\end{array}$ & $\begin{array}{l}\text { Pertambahan } \\
\text { bobot }(\%)\end{array}$ & $\begin{array}{l}\text { Tinggi } \\
(\mathrm{cm})\end{array}$ & $\begin{array}{c}\text { Cabang } \\
\text { /tanaman }\end{array}$ & $\begin{array}{l}\text { Pertambahan } \\
\text { bobot }(\%)\end{array}$ & $\begin{array}{l}\text { Tinggi } \\
(\mathrm{cm})\end{array}$ & $\begin{array}{c}\text { Cabang } \\
\text { /tanaman }\end{array}$ & $\begin{array}{r}\text { Pertamb } \\
\text { bobot }\end{array}$ \\
\hline \multirow[t]{2}{*}{ Cilibangi 4} & n.a & 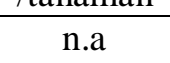 & & $25,4 b c^{2)}$ & $73,5 a^{2)}$ & $68,1 \mathrm{a}^{2)}$ & $34,7 \mathrm{abc}$ & $53,8 \mathrm{a}$ & $41,1 \mathrm{bc}$ & $46,1 \mathrm{ab}$ & $58,7 \mathrm{a}$ & $55,5 \mathrm{ab}$ \\
\hline & $37,9 \mathrm{~A}$ & 71 , & 183 & $28,7 \mathrm{AB}^{3)}$ & $21,1 \mathrm{~B}^{3)}$ & $46,1 \mathrm{~B}^{3)}$ & $25,1 \mathrm{~B}$ & & & & & \\
\hline \multirow[t]{2}{*}{ Cilibangi 5} & n.a & & 11 & & & 2 & $19,8 b c$ & 17 & & $27,6 a b$ & $8 \mathrm{a}$ & $29,8 \mathrm{~b}$ \\
\hline & $29,5 \mathrm{~A}$ & $57,0 \mathrm{~A}$ & $179,8 \mathrm{~A}$ & & & & $22,9 \mathrm{~A}$ & & & $20,3 \mathrm{~A}$ & $37,5 \mathrm{~A}$ & $126,14 \mathrm{~A}$ \\
\hline \multirow{2}{*}{ Cilibangi 6} & & & & & 65 & & 45,2 & & & & & \\
\hline & & & & & & & & & & & & \\
\hline \multirow[t]{2}{*}{ Helem } & $\mathrm{n}$ & & & & 51, & & $24,9 a b c$ & 69 & & $47,3 \mathrm{a}$ & $49,6 \mathrm{a}$ & $6,8 \mathrm{a}$ \\
\hline & $28,4 \mathrm{~A}$ & $49,5 \mathrm{~A}$ & 152 & & & & $21,4 \mathrm{AB}$ & & & $5,0 \mathrm{~B}$ & B & $8,8 \mathrm{~B}$ \\
\hline \multirow[t]{2}{*}{ Jatilaba } & & & & & & & & & & & & \\
\hline & & 49 , & & & & & & & & $1 \mathrm{~A}$ & & \\
\hline \multirow{2}{*}{ Tit Bulat } & & & & 44, & & & $53,5 \mathrm{a}$ & & 80 & $49,2 \mathrm{a}$ & $65,7 \mathrm{a}$ & \\
\hline & $29,5 \mathrm{~A}$ & $38,3 \mathrm{~A}$ & $182,3 \mathrm{~A}$ & & & $12,16 \mathrm{C}$ & $13,5 \mathrm{~B}$ & $10,5 \mathrm{~B}$ & $25,33 \mathrm{BC}$ & $15,2 \mathrm{~B}$ & $14,0 \mathrm{~B}$ & $45,5 \mathrm{~B}$ \\
\hline \multirow[t]{2}{*}{ Tit Segitiga } & & & & & & & $46,9 \mathrm{ab}$ & & & $47,5 \mathrm{a}$ & & $81,7 \mathrm{a}$ \\
\hline & 30,8 & 47, & & & & & & & & & & \\
\hline \multirow{2}{*}{ Tit Super } & & & & $\mathrm{c}$ & & 23 & $28,7 \mathrm{abc}$ & & & $16,4 \mathrm{~b}$ & & $32,4 \mathrm{~b}$ \\
\hline & $28,9 \mathrm{~A}$ & $50,0 \mathrm{~A}$ & $211,3 \mathrm{~A}$ & $22,4 \mathrm{~B}$ & $35,3 \mathrm{~B}$ & $168,1 \mathrm{AB}$ & $20,8 \mathrm{AB}$ & $34,8 \mathrm{AB}$ & $72,32 \mathrm{~B}$ & $24,3 \mathrm{AB}$ & $33,5 \mathrm{AB}$ & $135,3 \mathrm{AB}$ \\
\hline \multirow{2}{*}{ Tampar } & n.a & n.a & $\mathrm{n}$ & $8,3 \mathrm{c}$ & $36,8 b c$ & $20,2 b$ & $16,3 \mathrm{c}$ & $47,1 \mathrm{a}$ & $44,5 \mathrm{abc}$ & $38,2 \mathrm{ab}$ & $64,7 \mathrm{a}$ & $69,8 \mathrm{ab}$ \\
\hline & $35,7 \mathrm{~A}$ & $53,5 \mathrm{~A}$ & $323,3 \mathrm{~A}$ & $33,3 \mathrm{~A}$ & $32,0 \mathrm{~A}$ & $257,2 \mathrm{AB}$ & $29,3 \mathrm{AB}$ & $27,5 \mathrm{~A}$ & $174,5 \mathrm{BC}$ & $20,6 \mathrm{~B}$ & $17,6 \mathrm{~B}$ & $98,23 \mathrm{C}$ \\
\hline
\end{tabular}

Keterangan:

${ }^{1)}$ Tinggi tanaman cabai diukur pada saat tanaman berumur 5 minggu setelah tanam, jumlah cabang dihitung pada saat tanaman berumur 11 ming gu setelah tanam dan bobot buah dihitung pada 2 kali periode pembungaan

${ }^{2)}$ Persen penghambatan tinggi tanaman setiap kultivar; pada perlakuan kontrol tidak ada persen penghambatan tinggi tanaman, persen penghambatan jumlah cabangsetiap kultivar; pada perlakuan kontrol tidak ada persen penghambatan jumlah cabang, persen penghambatan bobot buah setiap kultivar; pada perlakuan kontrol tidak ada persen penghambatan pertambahan bobot

${ }^{3)}$ Rata-rata tinggi tanaman, rata-rata bobot buah dan rata-rata jumlah cabang setiap kultivar

Angka-angka yang diikuti oleh huruf yang sama pada kolom (huruf kecil) dan baris (huruf besar) yang sama tidak berbeda nyata berdasarkan DMRT 5\% 
menganggu metabolisme karbohidrat dengan memicu lintasan oksidatif pentosa fosfat, glikolisis, siklus tricarboxylic acid dan transfer elektron oksidatif, sehingga tanaman mengalami gangguan pertumbuhan dan perkembangan.

Inokulasi campuran CMV dan ChiVMV tidak selalu menyebabkan penurunan bobot buah yang lebih tinggi dibandingkan inokulasi tunggal CMV atau ChiVMV. Hal yang sama juga teramati untuk pengaruhnya terhadap penghambatan tinggi tanaman dan jumlah cabang. Subekti et al. (2006) mendapatkan hasil yang berbeda dengan kultivar cabai yang berbeda. Kultivar cabai Prabu, Laris, Jatilaba, Keriting Bogor, dan Taro mengalami laju penghambatan yang lebih besar dengan perlakuan inokulasi ganda CMV dan ChiVMV dibandingkan perlakuan inokulasi tunggal. Perbedaan hasil tersebut menunjukkan bahwa keparahan penyakit yang muncul terkait dengan interaksi antara CMV dan ChiVMV dengan kultivar tanaman cabai.

Respon Ketahanan Kultivar Cabai terhadap CMV dan ChiVMV. Pengelompokan tipe ketahanan kultivar cabai telah dilakukan berdasarkan hasil pengamatan kejadian penyakit, deteksi ELISA, dan analisis pengurangan bobot buah per tanaman. Tampak bahwa masing-masing kultivar cabai menghasilkan respon ketahanan yang berbeda-beda untuk masing-masing perlakuan inokulasi virus.
Respon kultivar cabai terhadap inokulasi CMV dapat dikelompokkan menjadi toleran (Cilibangi 5, Jatilaba, Tit Super, dan Tampar), rentan (Cilibangi 4, Helem, Tit Bulat, dan Tit Segitiga), dan sangat rentan (Cilibangi 6) (Tabel 6). Demikian pula respon kultivar cabai terhadap inokulasi ChiVMV dapat dikelompokkan menjadi toleran (Cilibangi 4, Cilibangi 5), rentan (Helem, Jatilaba, Tit Segitiga, dan Tit Super), dan sangat rentan (Cilibangi 6, dan Tit Bulat) (Tabel 7). Sedikit berbeda dengan respon kultivar cabai terhadap inokulasi campuran CMV dan ChiVMV yang hanya dapat dikelompokkan menjadi toleran (Cilibangi 5, dan Tit Super) dan rentan (Cilibangi 4, Cilibangi 6, Helem, Jatilaba, Tit Bulat, Tit Segitiga, dan Tampar) (Tabel 8).

Hasil evaluasi kultivar cabai yang dilakukan menunjukkan bahwa kultivar Jatilaba termasuk kultivar toleran terhadap CMV. Sebelumnya Nurhayati (1997) juga telah melaporkan bahwa Jatilaba termasuk kultivar yang toleran terhadap CMV. Hal ini menunjukkan bahwa ketahanan kultivar Jatilaba masih stabil, sehingga dapat direkomendasikan untuk digunakan sebagai material genetik untuk disilangkan dengan kultivar lain yang mempunyai tipe ketahanan lebih baik. Sulandari (komunikasi pribadi, 2004) menyatakan bahwa kultivar Tit Super memiliki respon agak tahan terhadap infeksi geminivirus, sementara pada penelitian ini respon Tit Super termasuk dalam

Tabel 6. Tipe ketahanan sembilan kultivar cabai merah terhadap inokulasi CMV.

\begin{tabular}{lcccl}
\hline \multirow{2}{*}{ Kultivar } & \multicolumn{4}{c}{ Respon Tanaman } \\
\cline { 2 - 4 } & Gejala & Hasil & $\begin{array}{c}\text { Pengurangan } \\
\text { Bobot Buah }\end{array}$ & Tipe Ketahanan \\
\hline Cilibangi-4 & + & ++ & + & Rentan \\
Cilibangi-5 & ++ & ++ & - & Toleran \\
Cilibangi-6 & ++ & ++ & + & Sangat Rentan \\
Helem & + & + & + & Rentan \\
Jatilaba & ++ & ++ & - & Toleran \\
Tit Bulat & + & ++ & + & Rentan \\
Tit Segitiga & + & ++ & + & Rentan \\
Tit Super & $+/-$ & + & - & Toleran \\
Tampar & $+/-$ & + & - & Toleran \\
\hline
\end{tabular}

Keterangan: penjelasan tentang respon tanaman lihat Tabel 1 
Tabel 7. Tipe Ketahanan sembilan kultivar cabai merah terhadap inokulasi ChiVMV

\begin{tabular}{lcccl}
\hline \multirow{2}{*}{ Kultivar } & \multicolumn{4}{c}{ Respon Tanaman } \\
\cline { 2 - 4 } & Gejala & $\begin{array}{c}\text { Hasil } \\
\text { ELISA }\end{array}$ & $\begin{array}{c}\text { Pengurangan } \\
\text { Bobot buah }\end{array}$ & Tipe Ketahanan \\
\hline Cilibangi-4 & ++ & ++ & - & Toleran \\
Cilibangi-5 & + & + & - & Toleran \\
Cilibangi-6 & ++ & ++ & + & Sangat Rentan \\
Helem & + & + & + & Rentan \\
Jatilaba & + & ++ & + & Rentan \\
Tit Bulat & ++ & + & + & Sangat Rentan \\
Tit Segitiga & ++ & ++ & + & Rentan \\
Tit Super & + & + & + & Toleran \\
Tampar & + & + & + & Rentan \\
\hline
\end{tabular}

Keterangan: penjelasan tentang respon tanaman lihat Tabel 1

Tabel 8. Tipe ketahanan sembilan kultivar cabai terhadap inokulasi campuran CMV dan ChiVMV

\begin{tabular}{|c|c|c|c|c|}
\hline \multirow[b]{2}{*}{ Kultivar } & \multicolumn{3}{|c|}{ Respon Tanaman } & \multirow[b]{2}{*}{ Tipe Ketahanan } \\
\hline & Gejala & Hasil ELISA & $\begin{array}{c}\text { Pengurangan } \\
\text { Bobot Buah }\end{array}$ & \\
\hline Cilibangi-4 & + & + & + & Rentan \\
\hline Cilibangi-5 & ++ & ++ & - & Toleran \\
\hline Cilibangi-6 & + & + & + & Rentan \\
\hline Helem & ++ & + & + & Rentan \\
\hline Jatilaba & + & + & + & Rentan \\
\hline Tit Bulat & ++ & ++ & + & Rentan \\
\hline Tit Segitiga & ++ & + & + & Rentan \\
\hline Tit Super & ++ & + & - & Toleran \\
\hline Tampar & + & + & + & Rentan \\
\hline
\end{tabular}

Keterangan: penjelasan tentang respon tanaman lihat Tabel 1

kelompok toleran untuk infeksi campuran CMV dan ChiVMV. Kedua informasi ini merupakan dasar untuk tindak lanjut pengujian kultivar cabai terhadap beberapa patogen penting lainnya seperti penyebab layu bakteri atau antraknosa, sehingga ada harapan untuk mendapatkan varietas yang tahan atau toleran terhadap beberapa macam patogen.

Meskipun tidak diperoleh kultivar cabai dengan respon tahan namun pada penelitian ini diperoleh kultivar dengan respon toleran terhadap infeksi CMV, ChiVMV, dan campuran CMV dan ChiVMV. Kultivar toleran memiliki arti cukup penting dalam upaya mengurangi kerugian akibat infeksi CMV dan
ChiVMV. Tanaman yang toleran terhadap virus adalah tanaman yang rentan terhadap infeksi virus, tetapi tidak menunjukkan gejala yang jelas atau menghasilkan gejala laten (Cooper \& Jones 1983). Keller et al. (2000) mendefinisikan bahwa tanaman toleran memiliki kemampuan untuk bertahan terhadap keberadaan dan multiplikasi patogen yang dapat ditunjukkan dengan berkurangnya gejala penyakit dan kemampuan membatasi kehilangan hasil. Lapidot et al. (1997) juga menyatakan bahwa kultivar yang toleran memiliki kemampuan untuk bertahan terhadap infeksi namun tidak mampu membatasi multiplikasi virus. Lebih lanjut Valleau ( 1952 dalam Goodman 
1987) berhasil membuktikan bahwa tanaman Ambalema tobacco yang toleran terhadap TMV berhasil mereduksi akumulasi virus dibandingkan pada tanaman rentan terutama pada daun-daun di bagian atas.

\section{SIMPULAN}

Evaluasi ketahanan yang dilakukan pada sembilan kultivar cabai menunjukkan bahwa kultivar komersial yang digunakan tidak memiliki ketahanan terhadap infeksi CMV maupun ChiVMV. Infeksi CMV atau ChiVMV dapat dikenali dari gejala yang muncul, dan juga dari pengaruhnya terhadap penghambatan pertumbuhan tanaman. Penghambatan tertinggi terhadap tinggi tanaman, jumlah cabang, dan bobot buah dapat mencapai berturut-turut 69\%, $87,5 \%$, dan 98,6\%. Kultivar Tit Segitiga, Tit Super, dan Tampar memiliki potensi produksi yang lebih tinggi dibandingkan kultivar lainnya tetapi tidak memiliki sifat ketahanan yang cukup baik. Kultivar Cilibangi 5 bersifat toleran terhadap CMV dan ChiVMV tetapi tidak memiliki potensi produksi yang cukup baik. Evaluasi terhadap sumber-sumber genetik atau genotipe tanaman yang lebih luas sangat dibutuhkan sebagai upaya pemuliaan tanaman untuk mendapatkan kultivar dengan sifat-sifat unggul yang dikehendaki.

\section{SANWACANA}

Penelitian ini merupakan bagian dari penelitian kerjasama antara Fakultas Pertanian Institut Pertanian Bogor dengan Asian Vegetable Research Development Center (AVRDC-Taiwan). Penulis mengucapkan terimakasih atas dukungan dananya. Kepada Ir. Yoyo Sulyo MS yang telah membantu menyediakan beberapa isolat CMV penulis ucapkan terima kasih.

\section{DAFTAR PUSTAKA}

Antoni, W, J.F., R.F. White, \& W. Zie . 1990. Cryptic viruses of beet and other plant. Dalam: Fraser RSS (editor) Recognition and response in plantviruse interactions. Springer Verlag. Heideberg.

Christopher, J.L., M. A. Lawton, M. Dron, \& R.A. Dixon. 1989. Signal and transduction mechanisms for activation of plant defenses against microbial attack. Cell Press 56: 215 224.

Cooper, J.L., \& A.T. Jones. 1983. Responses of plant to viruses : Proposal for the use of terms. Phytopathology 73: 127 - 128.

Fraser, R.S.S. 1992. The Genetics of Plant Virus Interaction Implication for Plant Breeding. Euphytica 63:175-185.

Goodman, R. N., Z. Kiraly \& K.R. Wood. 1986. The Biochemistry and Physiology of Plant Diseases. University of Missouri press. Columbia.

Green, S.K. 1991. Guidelines for Diagnostik Work in Plant Virology. AVRDC technical bulletin 15.

Hull, R.2002. Matthews' Plant Virology. Fourth Ed. San Diego: Academic Press

Keller, B., Feuillet, \& Messmer. 2000. Genetic of diseases resistance. dalam Slusarenko, A., R.S.S. Fraser, \& van Loon LC (editors), Mechanisms of Resistance to Plant Diseases. Kluwer Academic Publishers.

Lapidot, M., I. Paran, R. Ben-Joseph , S. Ben-Harush, M. Pilowsky, S. Cohen, \& C. Shifriss. 1997. Tolerance to cucumber mosaic virus in pepper: Development of advanced breeding lines and evaluation of virus level. Plant Dis. 81 : 185188.

Matthews, R.E.F. 1991. Plant Virology. Academic Press. San Fransisco.

Nurhayati. 1997. Pengaruh infeksi tunggal dan campuran TMV, CMV, dan PVY terhadap tiga kultivar cabai besar (C. annuum L.). Thesis Pascasarjana. IPB.

Palukaitis, P., M.J. Roossinck ., R.G. Dietzgen, \& R.I.B. Francki. 1992. Cucumber mosaic virus. Adv. Virus Res. 41:281-346.

Subekti, D., S.H. Hidayat, E. Nurhayati, \& S. Sujiprihati. 2006. Infeksi Cucumber mosaic virus dan Chilli veinal mottle virus terhadap 
pertumbuhan dan hasil tanaman cabai. Hayati 13: $53-57$.

Sulyo Y, \& A.S. Duriat. 1996. Field evaluation of pepper accesions for resistance to viruses. Di dalam : Proceeding of the AVNET II Midterm Workshop AVRDC, ADB and PCARRD. Laguna Philippines, 21-25 Februari 1995, hlm 132-137.

Sulyo Y. 1984. Penurunan Hasil Beberapa Varietas Lombok Akibat Infeksi CMV di Rumah Kaca. Laporan Hasil Penelitian. Balai Penelitian Hortikultura Lembang 1982/1983.

Taufik M., S.H. Hidayat, G. Suastika, S.M. Sumaraw, \& S. Sujiprihati. 2005. Kajian Plant Growth Promoting Rhizobacteria sebagai agens proteksi Cucumber mosaic virus dan Chilli veinal mottle virus pada Cabai. Hayati 12: 139 - 144.
Taufik, M., A.P. Astuti, \& S.H. Hidayat. 2005. Survei infeksi Cucumber mosaic virus dan Chilli veinal mottle virus pada tanaman cabai dan seleksi ketahanan beberapa kultivar cabai. Agrikultura 16: $146-152$.

Van Regenmortel M.H.V., \& M.C. Dubs. 1993. Serological procedures. Didalam : Matthews REF (ed). Diagnosis of Plant Virus Diseases. Boca Raton: CRC Press.

Voyles BA. 2002. The Biology of Viruses, second edition. McGrraw Hill 